\title{
Quantification and speciation of mercury in soils from the Tripuí Ecological Station, Minas Gerais, Brazil
}

\author{
Helena E.L. Palmieri ${ }^{\text {a,* }}$, Hermínio A. Nalini Jr. ${ }^{b}$, Liliam V. Leonel ${ }^{\text {a }}$, \\ Cláudia C. Windmöller ${ }^{\mathrm{c}}$, Regis C. Santos ${ }^{\mathrm{a}}$, Walter de Brito ${ }^{\mathrm{a}}$ \\ a Nuclear Technology Development Centre/National Commission for Nuclear Energy, Caixa Postal 941, Belo Horizonte, Minas Gerais, Brazil \\ ${ }^{\mathrm{b}}$ Federal University of Ouro Preto, Geological Department, Morro do Cruzeiro, s/n, Ouro Preto, Minas Gerais, Brazil \\ ${ }^{\mathrm{c}}$ Federal University of Minas Gerais, ICEx, Chemistry Department, Antonio Carlos av., 6627, Belo Horizonte, Minas Gerais, Brazil
}

Received 15 October 2004; received in revised form 12 May 2005; accepted 26 September 2005

Available online 27 December 2005

\begin{abstract}
Contents of total mercury, organic carbon, total sulfur, iron, aluminum and grain size and clay mineralogy were used along with Pearson's correlation and $\mathrm{Hg}$ thermal desorption technique to investigate the presence, distribution and binding behavior of $\mathrm{Hg}$ in soils from three depths from the Tripuí Ecological Station, located near Ouro Preto, Minas Gerais State, Brazil. The soils studied had predominantly medium and fine sand texture $(0.59-0.062 \mathrm{~mm})$, acid character and $\mathrm{Hg}$ contents ranging from 0.09 to $1.23 \mu \mathrm{g} / \mathrm{g}$. The granulometric distribution revealed that $\mathrm{Hg}$ is associated with coarse sand $(2-0.59 \mathrm{~mm})$ and silt and clay $(<0.062 \mathrm{~mm})$ and presents similar Hg concentrations in both fractions. Mercury distribution in soil profiles showed that $\mathrm{Hg}$ was homogeneously distributed throughout the depths at most sites. $\mathrm{Hg}$ thermal desorption curves show that mercury occurs not only as $\mathrm{Hg}^{2+}$ predominantly bound to organic components in most of the samples, but also in the form of cinnabar in some. Pearson's correlation confirmed that mercury is associated with organic matter and sulfur and possibly with sulfur-bearing organic matter in most samples.
\end{abstract}

(C) 2005 Elsevier B.V. All rights reserved.

Keywords: Mercury; Soils; Tripuí Ecological Station; CVAAS; Hg thermal desorption

\section{Introduction}

For decades, the Tripuí Ecological Station (TES) has been the object of interest of many studies due to its historical, ecological, and environmental importance. It was turned into an ecological station in 1981 due to the discovery of the invertebrate, Peripatus acacioi, a prob-

\footnotetext{
* Corresponding author. Centro de Desenvolvimento da Tecnologia Nuclear, Serviço de Química e Radioquímica, Caixa Postal 941 CEP30.123-970 Belo Horizonte, Minas Gerais, Brazil. Tel.: +55 313499 3181; fax: +553134993550.

E-mail address: help@cdtn.br (H.E.L. Palmieri).
}

able ancestor of annelids and arthropods (Guimarães Neto, 1999) in 1954. It lies in Quadrilátero Ferrífero, a region of rudimentary gold mining in the late 17th century (Eschewge, 1979; Guimarães Neto, 1999). Even though there is no evidence that gold miners might have used $\mathrm{Au}-\mathrm{Hg}$ amalgamation in the TES area (Busher, 1992), mercury was found in sediments and some plant species as reported by Cruz (2002), Busher (1992) and Palmieri et al. (2003).

Mercury occurs on Earth's crust as more than 20 minerals. Cinnabar $(\mathrm{HgS})$ and the free mercury $\left(\mathrm{Hg}^{0}\right)$ are the main natural mercury sources found in soils and aquatic environments (Salomons et al., 1995). Due to 
the extremely low solubility of $\mathrm{HgS}\left(10^{-54} \mathrm{~mol} \mathrm{dm}^{-3}\right)$, it has fundamental importance in the immobilization of $\mathrm{Hg}$ under low oxygenation and in slightly oxidant-toreducing environmental conditions. However, under altered conditions, it may become soluble (Moore and Ramamoorthy, 1984).

Depending on redox conditions, inorganic $\mathrm{Hg}$ may occur in three different states, $\mathrm{Hg}_{2}^{2+}, \mathrm{Hg}^{0}$, and $\mathrm{Hg}^{2+}$. The last two are normally found in soil. $\mathrm{pH}$ and $\mathrm{Cl}^{-1}$ concentration are also key parameters in determining the speciation and the chemical transformations of mercury in soil solution. Due to the large susceptibility of $\mathrm{Hg}^{2+}$ to form complexes, only a minute fraction of this ion occurs in soil solution. The major fraction is either bound to soil minerals or adsorbed onto solid inorganic and organic surfaces (Steinnes, 1995).

Anderson (1979) demonstrated a close correlation between $\mathrm{Hg}$ and organic matter in acid soils, whereas in slightly acid and neutral soils $(\mathrm{pH}>6)$, the co-variation between $\mathrm{Hg}$ and $\mathrm{Fe}$ was stronger than that between $\mathrm{Hg}$ and organic matter. The formation of organic $\mathrm{Hg}$ complexes is largely due to the affinity of $\mathrm{Hg}^{2+}$ and its inorganic compounds for sulfur-containing functional groups (Shuster, 1991; Xia et al., 1999).

Due to the high affinity of $\mathrm{Hg}$ for organic matter and minerals, soil $\mathrm{Hg}$ leaching rates are very low and are mostly associated with dissolved organic matter
(Anderson, 1979; Shuster, 1991; Mierle and Ingram, 1991).

The determination of $\mathrm{Hg}$ by thermal desorption/ atomic absorption technique was initially applied in geochemical prospection (Azzaria and Webber, 1969), and in recent years, it has proved to be useful to distinguish different $\mathrm{Hg}$-binding forms (Hg phases) by their thermal release characteristics (Windmöller et al., 1996; Biester et al., 2000; Higueras et al., 2003).

The aim of this work was to investigate the presence, distribution and binding behavior of $\mathrm{Hg}$ in soil samples collected at three depths on the banks of the main streams and near a pond in TES. Total Hg was determined by cold vapor atomic absorption spectrometry (CVAAS) and $\mathrm{Hg}$ phases were determined by thermal desorption atomic absorption spectrometry (TDAAS). Factors that govern the mobility of mercury such as organic carbon, $\mathrm{pH}$, total sulfur, iron and aluminum contents and clay mineralogy were also examined.

\section{Study area}

The area studied lies between UTM coordinates " 23 $\mathrm{K} ; 648000 / 653000 \mathrm{E}$ and $7743500 / 7747500 \mathrm{~N}$ " and comprises an area of approximately $7 \mathrm{~km}^{2}$. The Tripuí Ecological Station (TES) (Fig. 1) has an area of 3.37 $\mathrm{km}^{2}$ and is located in the Tripuí Stream valley, about 3

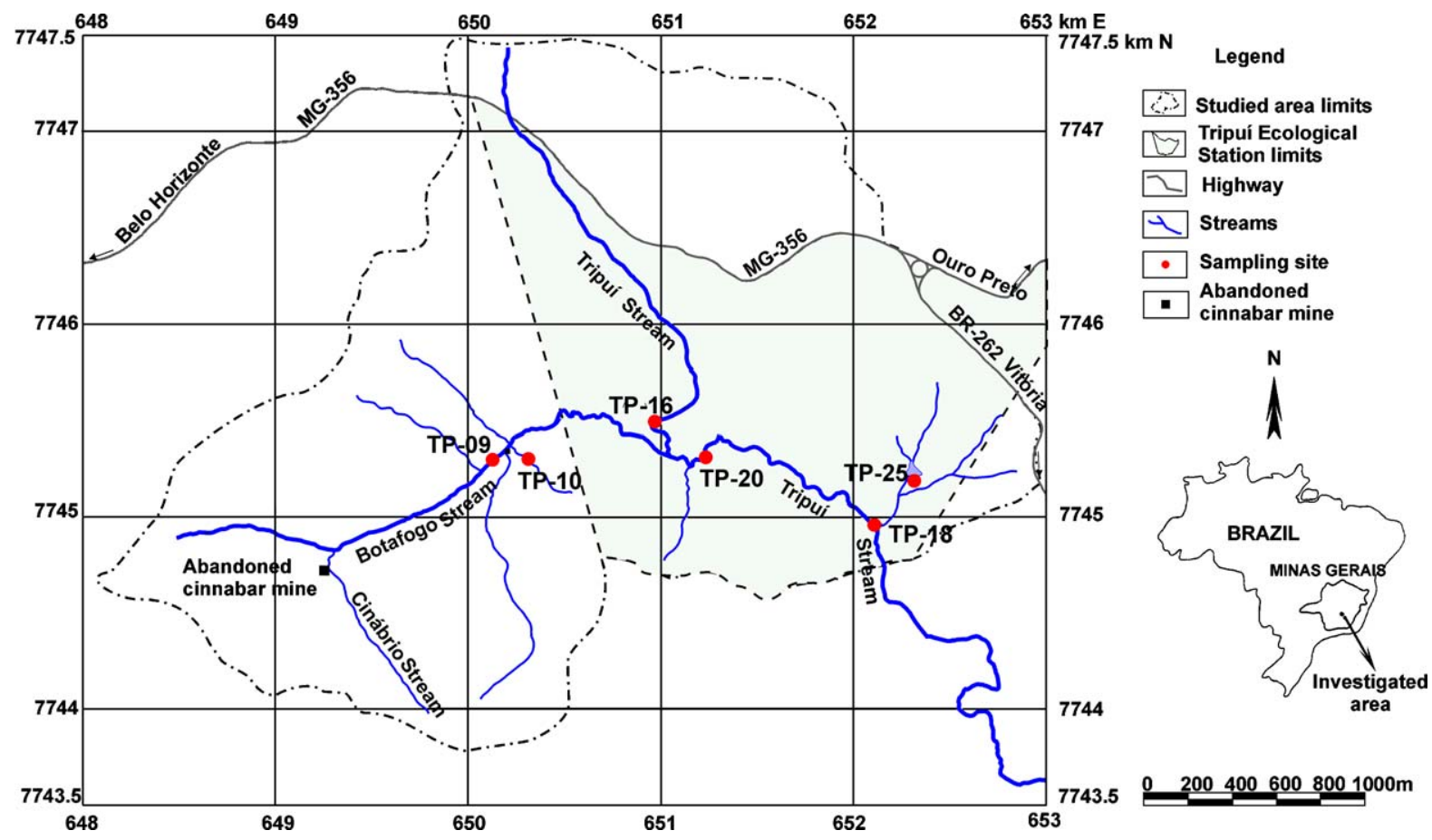

Fig. 1. Sampling site location in the area investigated in Minas Gerais State, Brazil. 
km away from Ouro Preto City. One of the main tributaries of Tripuí Stream, Botafogo Stream, flows fast and its riversides present dense vegetation. It meets the Cinábrio Stream at its source, which drains the surroundings of an abandoned cinnabar mine.

\section{Methods}

\subsection{Sample collection and grain size fractionation}

Soil samples were collected on stream banks in February 2003 at the following sites: TP-09 (Botafogo Stream), TP-10 (a tributary of Botafogo Stream), TP-16 (Tripuí Stream upstream its confluence with Botafogo Stream), TP-18 and TP-20 (Tripuí Stream downstream its confluence with Botafogo Stream), TP-25 (Fortes pond shore). One track sediment sample (SDT) was also collected at TP-09. Sampling sites are shown in Fig. 1, and sample identifications are given in Table 1.

Approximately $0.5 \mathrm{~kg}$ of soil was collected at three different depths, 30, 60 and $90 \mathrm{~cm}$, at all sampling sites using a deep sampling handle (JMC back-saver handle). Samples were kept in polyethylene bags and air dried and fractionated in laboratory by sieving in three grain sizes $(2-0.59 \mathrm{~mm}, 0.59-0.062 \mathrm{~mm}$, and $<0.062 \mathrm{~mm}$ ) to determine the relation between particle size and $\mathrm{Hg}$ retention. Each fraction was weighed and the percent weight of the each fraction was calculated (Table 1).

\subsection{Analytical techniques}

To determine total mercury, $0.20-0.30 \mathrm{~g}$ of soil samples was digested with a mixture of $\mathrm{HNO}_{3} / \mathrm{H}_{2} \mathrm{SO}_{4}$ $(1: 2, \mathrm{v} / \mathrm{v})$, potassium permanganate, potassium persulfate in a closed Teflon vessel $(22 \mathrm{ml})$ at $75{ }^{\circ} \mathrm{C}$ for $16 \mathrm{~h}$. Before analysis, hydroxylamine hydrochloride was added to reduce excess permanganate, and the sample was diluted to $50 \mathrm{ml}$ with deionized water. Total mercury was determined by CVAAS using a Perkin Elmer flow-injection mercury system, FIMS 400 (detection limit of $5 \mathrm{ng} / \mathrm{g}$ ). Standard reference material 2709, San Joaquim soil $1.40 \pm 0.08 \mu \mathrm{g} / \mathrm{g} \mathrm{Hg}$ from the National Institute of Standards and Technology (NIST), USA and GBW $074040.590 \pm 0.034 \mu \mathrm{g} / \mathrm{g} \mathrm{Hg}$ from the National Research Center, China, were used to evaluate the analytical accuracy within 5\%. The concentrations measured were $1.32 \pm 0.14 \mu \mathrm{g} / \mathrm{g} \mathrm{Hg}$ and $0.60 \pm 0.07 \mu \mathrm{g} /$ $\mathrm{g} \mathrm{Hg}$, dry weight, with recovery rates of $94 \%$ and $102 \%$, respectively. Moisture was determined by weight loss in a separate sub-sample by drying at $110{ }^{\circ} \mathrm{C}$ for $2 \mathrm{~h}$.
For $\mathrm{pH}$ determination, dry soil was mixed with 12.5 -fold its water weight and shaken. Measurement was carried out in the supernatant solution $60 \mathrm{~min}$ after preparation using Metrohm $744 \mathrm{pH}$ meter.

Determination of $\mathrm{Hg}$ phases by solid-phase $\mathrm{Hg}$ thermal desorption is based on the specific thermal desorption or decomposition of $\mathrm{Hg}$ compounds from solids at different temperatures. Hg thermal desorption curves (TDCs) were obtained according to Windmöller et al. (1996). The system consists of an electronically controlled heating unit and an $\mathrm{Hg}$ detection unit. The samples (masses varying from 500 to $3000 \mathrm{mg}$ ) were heated at a rate of $33{ }^{\circ} \mathrm{C} / \mathrm{min}$ from room temperature to $570{ }^{\circ} \mathrm{C}$. A constant nitrogen flow $(200 \mathrm{ml} / \mathrm{min})$ passed through the samples carried thermodesorbed vapors to the detection cell of an atomic absorption spectrometer (GBC 932-AA). Mercury was detected at $253.7 \mathrm{~nm}$. Interference, mainly from pyrolytic organic matter, was compensated by continuous deuterium background correction. The $\mathrm{Hg}$ TDC shows the release of $\mathrm{Hg}^{0}$ vs. temperature.

Mercuric sulfide red (99\%, Fluka) and cinnabar found in the region studied were used as standards for $\mathrm{Hg}$ thermal desorption curve of synthetic red cinnabar $(\mathrm{HgS})$ and natural red cinnabar. Standard materials were prepared by solid dilution with quartz powder. Standard $\mathrm{Hg}^{0}$ (Raposo et al., 2003) and standard $\mathrm{Hg}$ in humic acid (Valle, 2005) were obtained through the same thermal desorption/atomic absorption system and under the same work conditions.

The level of organic matter in soils was assessed by measuring organic carbon in all samples. Organic carbon was determined by the Walkley-Black method (EMBRAPA, 1997). This method is based on the oxidation of $\mathrm{C}$ by acid dichromate and titration of excess dichromate with ammonium iron(II) sulfate hexahydrate solution.

Iron, aluminum and sulfur were analyzed by X-ray fluorescence spectrometry (Rigaku 3134), and mineralogical analysis of the samples was carried out with a Rigaku X-ray diffractometer.

The physico-chemical parameters and $\mathrm{Hg}$ contents measured were analyzed using STATISTICA for Windows, version 6.0 for linear correlation (Pearson's correlation).

\section{Results and discussion}

\subsection{Sample characterization and $\mathrm{Hg}$ quantification}

X-ray diffraction analyses of bulk mineralogy reveal that the soil samples consist primarily of quartz $\left(\mathrm{SiO}_{2}\right)$, 
Table 1

Distributions of mercury and organic carbon concentrations in different size fractions at three soil depths

\begin{tabular}{|c|c|c|c|c|c|c|c|c|c|c|c|c|c|c|}
\hline \multirow{2}{*}{$\begin{array}{l}\text { Sampling } \\
\text { Sites }\end{array}$} & \multirow[t]{2}{*}{$\mathrm{pH}$ range } & \multirow{2}{*}{$\begin{array}{l}\text { Size fractions } \\
(\mathrm{mm})\end{array}$} & \multicolumn{4}{|c|}{ Depth $(30 \mathrm{~cm})$} & \multicolumn{4}{|c|}{ Depth $(60 \mathrm{~cm})$} & \multicolumn{4}{|c|}{ Depth $(90 \mathrm{~cm})$} \\
\hline & & & Sample & $\begin{array}{l}\text { Grain } \\
\text { size (\%) }\end{array}$ & $\mathrm{Hg}(\mu \mathrm{g} / \mathrm{g})$ & $\begin{array}{l}\text { Organic } \\
\text { carbon (\%) }\end{array}$ & Sample & $\begin{array}{l}\text { Grain } \\
\text { size (\%) }\end{array}$ & $\mathrm{Hg}(\mu \mathrm{g} / \mathrm{g})$ & $\begin{array}{l}\text { Organic } \\
\text { carbon (\%) }\end{array}$ & Sample & $\begin{array}{l}\text { Grain } \\
\text { size (\%) }\end{array}$ & $\mathrm{Hg}(\mu \mathrm{g} / \mathrm{g})$ & $\begin{array}{l}\text { Organic } \\
\text { carbon }(\%)\end{array}$ \\
\hline \multirow[t]{3}{*}{ ТР 09} & $5.1-5.6$ & $2.0-0.59$ & SA1d & 22 & $1.08 \pm 0.12$ & $5.0 \pm 0.2$ & SA2d & 13 & $1.23 \pm 0.12$ & $2.6 \pm 0.1$ & SA3d & 13 & $0.62 \pm 0.06$ & $3.8 \pm 0.2$ \\
\hline & & $0.59-0.062$ & SA1g & 61 & $0.91 \pm 0.09$ & $4.6 \pm 0.2$ & $\mathrm{SA} 2 \mathrm{~g}$ & 71 & $0.48 \pm 0.05$ & $2.0 \pm 0.1$ & SA3g & 72 & $0.39 \pm 0.04$ & $2.0 \pm 0.1$ \\
\hline & & $<0.062$ & SA1h & 17 & $1.18 \pm 0.12$ & $5.3 \pm 0.2$ & $\mathrm{SA} 2 \mathrm{~h}$ & 16 & $0.94 \pm 0.09$ & $2.7 \pm 0.1$ & SA3h & 15 & $0.79 \pm 0.08$ & $2.8 \pm 0.1$ \\
\hline \multirow[t]{3}{*}{ TP-10 } & $5.0-5.2$ & $2.0-0.59$ & SB1d & 24 & $0.21 \pm 0.02$ & $3.3 \pm 0.2$ & SB2d & 28 & $0.11 \pm 0.01$ & $1.0 \pm 0.1$ & SB3d & 23 & $0.09 \pm 0.02$ & $1.8 \pm 0.1$ \\
\hline & & $0.59-0.062$ & SB1g & 51 & $0.17 \pm 0.02$ & $3.1 \pm 0.2$ & SB2g & 40 & $0.15 \pm 0.01$ & $1.7 \pm 0.1$ & SB3g & 55 & $0.11 \pm 0.01$ & $2.1 \pm 0.1$ \\
\hline & & $<0.062$ & SB1h & 25 & $0.23 \pm 0.02$ & $3.5 \pm 0.2$ & SB2h & 32 & $0.17 \pm 0.02$ & $1.4 \pm 0.1$ & SB3h & 22 & $0.11 \pm 0.01$ & $1.4 \pm 0.1$ \\
\hline \multirow[t]{3}{*}{ TP-16 } & $5.1-5.7$ & $2.0-0.59$ & SC1d & 5 & $0.16 \pm 0.02$ & $6.8 \pm 0.2$ & $\mathrm{SC} 2 \mathrm{~d}$ & 12 & $0.28 \pm 0.03$ & $3.4 \pm 0.2$ & $\mathrm{SC} 3 \mathrm{~d}$ & 5 & $0.18 \pm 0.02$ & $4.6 \pm 0.2$ \\
\hline & & $0.59-0.062$ & SC1g & 68 & $0.12 \pm 0.01$ & $2.0 \pm 0.1$ & $\mathrm{SC} 2 \mathrm{~g}$ & 62 & $0.15 \pm 0.01$ & $1.9 \pm 0.1$ & SC3g & 57 & $0.12 \pm 0.01$ & $1.7 \pm 0.1$ \\
\hline & & $<0.062$ & SC1h & 27 & $0.16 \pm 0.02$ & $1.7 \pm 0.1$ & $\mathrm{SC} 2 \mathrm{~h}$ & 26 & $0.27 \pm 0.03$ & $2.1 \pm 0.1$ & $\mathrm{SC} 3 \mathrm{~h}$ & 38 & $0.25 \pm 0.02$ & $1.7 \pm 0.1$ \\
\hline \multirow[t]{3}{*}{ TP-18 } & $5.3-5.7$ & $2.0-0.59$ & SF1d & 12 & $0.27 \pm 0.03$ & $12.0 \pm 0.3$ & SF2d & 14 & $0.67 \pm 0.07$ & $4.8 \pm 0.2$ & SF3d & 24 & $0.70 \pm 0.07$ & $5.8 \pm 0.2$ \\
\hline & & $0.59-0.062$ & SF1g & 52 & $0.38 \pm 0.04$ & $3.9 \pm 0.2$ & SF2g & 42 & $0.55 \pm 0.05$ & $2.7 \pm 0.1$ & SF3g & 50 & $0.47 \pm 0.05$ & $2.9 \pm 0.1$ \\
\hline & & $<0.062$ & SF1h & 36 & $0.60 \pm 0.06$ & $3.5 \pm 0.2$ & SF2h & 44 & $0.75 \pm 0.07$ & $1.9 \pm 0.1$ & SF3h & 26 & $0.63 \pm 0.06$ & $2.4 \pm 0.1$ \\
\hline \multirow[t]{3}{*}{ TP-20 } & $5.2-5.7$ & $2.0-0.59$ & SD1d & 7 & $0.29 \pm 0.03$ & $2.7 \pm 0.1$ & $\mathrm{SD} 2 \mathrm{~d}$ & 10 & $0.22 \pm 0.02$ & $1.3 \pm 0.1$ & SD3d & 16 & $0.28 \pm 0.03$ & $0.8 \pm 0.1$ \\
\hline & & $0.59-0.062$ & SD1g & 80 & $0.22 \pm 0.02$ & $1.0 \pm 0.1$ & SD2g & 77 & $0.21 \pm 0.02$ & $0.8 \pm 0.1$ & SD3g & 75 & $0.24 \pm 0.02$ & $0.4 \pm 0.1$ \\
\hline & & $<0.062$ & SD1h & 13 & $0.37 \pm 0.04$ & $2.3 \pm 0.1$ & $\mathrm{SD} 2 \mathrm{~h}$ & 13 & $0.43 \pm 0.04$ & $1.6 \pm 0.1$ & SD3h & 9 & $0.39 \pm 0.04$ & $1.3 \pm 0.1$ \\
\hline \multirow[t]{3}{*}{ TP-25 } & $5.7-6.0$ & $2.0-0.59$ & SE1d & 9 & $0.76 \pm 0.08$ & $3.4 \pm 0.2$ & SE2d & 10 & $0.88 \pm 0.09$ & $2.7 \pm 0.1$ & SE3d & 10 & $0.88 \pm 0.09$ & $2.3 \pm 0.1$ \\
\hline & & $0.59-0.062$ & SE1g & 40 & $0.38 \pm 0.04$ & $1.4 \pm 0.1$ & SE2g & 40 & $0.53 \pm 0.05$ & $0.7 \pm 0.1$ & SE3g & 41 & $0.58 \pm 0.06$ & $1.2 \pm 0.1$ \\
\hline & & $<0.062$ & SE1h & 51 & $0.51 \pm 0.05$ & $<0.1$ & SE2h & 50 & $0.77 \pm 0.08$ & $<0.1$ & SE3h & 49 & $0.83 \pm 0.08$ & $<0.1$ \\
\hline
\end{tabular}


kaolinite $\left(\mathrm{Al}_{2} \mathrm{Si}_{2} \mathrm{O}_{5}(\mathrm{OH})_{4}\right)$, goethite $(\mathrm{FeO} \cdot \mathrm{OH})$ and muscovite $\left(\mathrm{KAl}_{2}\left(\mathrm{AlSi}_{3} \mathrm{O}_{10}\right)(\mathrm{OH})_{2}\right)$. Minor amounts of hematite $\left(\mathrm{Fe}_{2} \mathrm{O}_{3}\right)$, gibbsite $\left(\alpha-\mathrm{Al}_{2} \mathrm{O}_{3} \cdot 3 \mathrm{H}_{2} \mathrm{O}\right)$, magnetite $\left(\mathrm{Fe}_{3} \mathrm{O}_{4}\right)$, chlorite $\left(\mathrm{Mg}_{3}\left(\mathrm{Si}_{4} \mathrm{O}_{10}\right) \cdot(\mathrm{OH})_{2} \cdot \mathrm{Mg}_{3}(\mathrm{OH})_{6}\right)$ were also observed. The silt and clay fraction is predominantly composed of quartz, muscovite and kaolinite, with minor amounts of goethite, hematite and gibbsite. At TP-25, the predominant minerals were quartz, muscovite and kaolinite. Diffractograms of samples SA1d, SE2h, SF2d and SD1h are shown in Fig. 2.

The distribution of total mercury, organic carbon, Al, $\mathrm{Fe}$ and $\mathrm{S}$ concentrations in different grain-size fractions at three depths and at six sampling sites is summarized in Tables 1 and 2. The mercury concentrations presented in Table 1 are reported as $\mu \mathrm{g} / \mathrm{g}$ dry weight. Total mercury concentration in soil samples ranged from 0.09 to $1.23 \mu \mathrm{g} / \mathrm{g}$, significantly higher than the concentration of $<0.1 \mu \mathrm{g} / \mathrm{g}$ established by Fergusson (1990) for unpolluted soils. Hg content in the sediment sample (SDTh) was $0.62 \mu \mathrm{g} / \mathrm{g}$. The values obtained for organic carbon $(0.6-4.8 \%)$ agree with the typical content values of organic matter in tropical soils of South America (0.5-21.7\%) reported by Alloway (1995).

Soil was found to consist mainly of fine and medium sand texture $(0.59-0.062 \mathrm{~mm})$. Clay and silt ranged from $9 \%$ to $51 \%$. At site TP-25 (Fortes pond), the predominant size fraction was $<0.062 \mathrm{~mm}$. At this site, abundant fine grains were deposited. In most of the samples of this study, sand $(2-0.59 \mathrm{~mm})$ and silt and clay $(<0.062 \mathrm{~mm})$ fractions contained similar $\mathrm{Hg}$ concentrations. The same was observed for $\mathrm{Fe}, \mathrm{Al}$ and organic carbon (except at TP-25). Sulfur concentration appeared to be independent from particle size. The behavior of mercury in association with the finest granulometric class of clay in soil was observed in previous studies (Busher, 1992; Leoni and Sartori, 1997). According to Tessier et al. (1982), increased metal concentration in coarse fractions had already been observed, and it is believed that coarse particles may document anthropogenic inputs better because of their limited transport and longer residence time at any particular site.

Sample $\mathrm{pH}$ values were between 5.0 and 6.0. Hence, this acid soil can be associated with the humid climate of this region, where possibly frequent leaching tends to produce protonated clays, which lowers the $\mathrm{pH}$.

\subsection{Mercury phases in soils}

TDCs of standard mercury compounds or mercury binding forms, which might potentially occur in soils of TES, are shown in Fig. 3.

Hg TDCs were carried out in all samples, and the representative curves are shown in Fig. 4. Most of them display a characteristic pattern defined by peaks with one maximum between 280 and $380{ }^{\circ} \mathrm{C}$ (Fig. 4a). This suggests the presence of mercury in the form of $\mathrm{Hg}^{2+}$ bound to organic matter according to the curve of

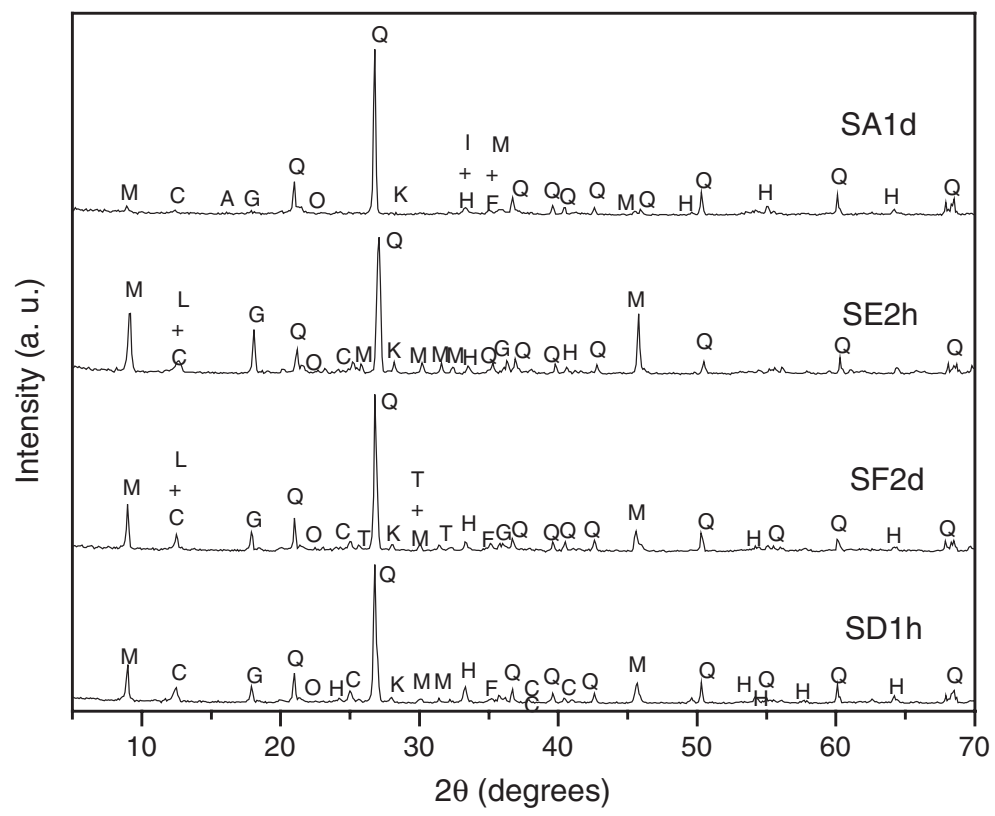

Fig. 2. Diffractograms of samples SA1d, SE2h, SF2d, and SD1h. Mineral peaks: M (muscovite); C (kaolinite); A (albite); L (chlorite); G (gibbsite); $\mathrm{Q}$ (quartz); O (goethite); H (hematite); T (tourmaline); K (microcline); I (ilmenite); F (magnetite). 
Table 2

Distributions of aluminum, iron, and sulfur concentrations in different size fractions at three soil depths

\begin{tabular}{|c|c|c|c|c|c|c|c|c|c|c|c|c|c|}
\hline \multirow[t]{2}{*}{ Sampling sites } & \multirow[t]{2}{*}{ Size fractions $(\mathrm{mm})$} & \multicolumn{4}{|c|}{ Depth $(30 \mathrm{~cm})$} & \multicolumn{4}{|c|}{ Depth $(60 \mathrm{~cm})$} & \multicolumn{4}{|c|}{ Depth $(90 \mathrm{~cm})$} \\
\hline & & Sample & $\mathrm{Al}(\%)$ & $\mathrm{Fe}(\%)$ & $\mathrm{S}(\mu \mathrm{g} / \mathrm{g})$ & Sample & $\mathrm{Al}(\%)$ & $\mathrm{Fe}(\%)$ & $\mathrm{S}(\mu \mathrm{g} / \mathrm{g})$ & Sample & $\mathrm{Al}(\%)$ & $\mathrm{Fe}(\%)$ & $\mathrm{S}(\mu \mathrm{g} / \mathrm{g})$ \\
\hline \multirow{3}{*}{ TP-09 } & $2.0-0.59$ & SA1d & $6.1 \pm 0.6$ & $12.4 \pm 1.2$ & $490 \pm 50$ & SA2d & $6.2 \pm 0.6$ & $11.7 \pm 1.2$ & $240 \pm 20$ & SA3d & $5.5 \pm 0.5$ & $11.1 \pm 1.1$ & $260 \pm 30$ \\
\hline & $0.59-0.062$ & SA1g & $6.1 \pm 0.6$ & $11.1 \pm 1.0$ & $490 \pm 50$ & SA2g & $5.3 \pm 0.5$ & $8.4 \pm 0.8$ & $200 \pm 20$ & SA3g & $4.6 \pm 0.5$ & $7.8 \pm 0.8$ & $190 \pm 20$ \\
\hline & $<0.062$ & SA1h & $6.6 \pm 0.7$ & $12.3 \pm 1.2$ & $520 \pm 50$ & $\mathrm{SA} 2 \mathrm{~h}$ & $8.1 \pm 0.8$ & $12.2 \pm 1.2$ & $260 \pm 30$ & SA3h & $7.5 \pm 0.7$ & $11.5 \pm 1.2$ & $240 \pm 20$ \\
\hline \multirow{3}{*}{ TP-10 } & $2.0-0.59$ & SB1d & $10.1 \pm 1.0$ & $6.1 \pm 0.6$ & $180 \pm 20$ & SB2d & $12.6 \pm 1.3$ & $5.2 \pm 0.5$ & $<100$ & SB3d & $11.9 \pm 1.2$ & $6.0 \pm 0.6$ & $140 \pm 10$ \\
\hline & $0.59-0.062$ & SB1g & $8.1 \pm 0.8$ & $4.6 \pm 0.5$ & $190 \pm 20$ & SB2g & $10.1 \pm 1.0$ & $4.4 \pm 0.4$ & $120 \pm 10$ & SB3g & $10.4 \pm 1.0$ & $4.7 \pm 0.5$ & $170 \pm 20$ \\
\hline & $<0.062$ & SB1h & $10.8 \pm 1.0$ & $6.9 \pm 0.7$ & $210 \pm 20$ & $\mathrm{SB} 2 \mathrm{~h}$ & $11.7 \pm 1.2$ & $6.0 \pm 0.6$ & $<100$ & SB3h & $11.7 \pm 1.2$ & $6.5 \pm 0.6$ & $130 \pm 10$ \\
\hline \multirow[t]{3}{*}{ TP-16 } & $2.0-0.59$ & SC1d & $6.2 \pm 0.6$ & $13.2 \pm 1.3$ & $450 \pm 40$ & $\mathrm{SC} 2 \mathrm{~d}$ & $7.7 \pm 0.8$ & $11.5 \pm 1.2$ & $260 \pm 30$ & $\mathrm{SC} 3 \mathrm{~d}$ & $7.1 \pm 0.7$ & $12.7 \pm 1.3$ & $250 \pm 20$ \\
\hline & $0.59-0.062$ & SC1g & $4.0 \pm 0.4$ & $9.6 \pm 1.0$ & $160 \pm 20$ & $\mathrm{SC} 2 \mathrm{~g}$ & $5.8 \pm 0.6$ & $9.0 \pm 0.9$ & $200 \pm 20$ & SC3g & $4.8 \pm 0.5$ & $8.7 \pm 0.9$ & $140 \pm 10$ \\
\hline & $<0.062$ & SC1h & $7.7 \pm 0.8$ & $18.8 \pm 1.9$ & $200 \pm 20$ & $\mathrm{SC} 2 \mathrm{~h}$ & $8.9 \pm 0.9$ & $15.3 \pm 1.5$ & $230 \pm 20$ & $\mathrm{SC} 3 \mathrm{~h}$ & $9.2 \pm 0.9$ & $14.8 \pm 1.5$ & $180 \pm 20$ \\
\hline \multirow[t]{3}{*}{ TP-18 } & $2.0-0.59$ & SF1d & $8.9 \pm 0.9$ & $8.4 \pm 0.8$ & $1370 \pm 140$ & SF2d & $9.7 \pm 1.0$ & $9.2 \pm 0.9$ & $500 \pm 50$ & SF3d & $9.2 \pm 0.9$ & $8.4 \pm 0.8$ & $600 \pm 60$ \\
\hline & $0.59-0.062$ & SF1g & $6.2 \pm 0.6$ & $5.5 \pm 0.5$ & $380 \pm 40$ & SF2g & $8.6 \pm 0.9$ & $6.7 \pm 0.7$ & $250 \pm 20$ & SF3g & $8.0 \pm 0.8$ & $6.9 \pm 0.7$ & $300 \pm 30$ \\
\hline & $<0.062$ & SF1h & $9.4 \pm 0.9$ & $10.1 \pm 1.0$ & $280 \pm 30$ & $\mathrm{SF} 2 \mathrm{~h}$ & $10.0 \pm 1.0$ & $9.4 \pm 0.9$ & $140 \pm 10$ & SF3h & $10.0 \pm 1.0$ & $9.3 \pm 0.9$ & $220 \pm 20$ \\
\hline \multirow[t]{3}{*}{ ТР-20 } & $2.0-0.59$ & SD1d & $6.2 \pm 0.6$ & $21.2 \pm 2.1$ & $220 \pm 20$ & SD2d & $8.4 \pm 0.8$ & $14.2 \pm 1.4$ & $<100$ & SD3d & $3.3 \pm 0.3$ & $14.8 \pm 1.5$ & $<100$ \\
\hline & $0.59-0.062$ & SD1g & $3.7 \pm 0.4$ & $11.8 \pm 1.2$ & $<100$ & SD2g & $8.3 \pm 0.8$ & $14.1 \pm 1.4$ & $<100$ & SD3g & $4.1 \pm 0.4$ & $15.2 \pm 1.5$ & $<100$ \\
\hline & $<0.062$ & SD1h & $6.7 \pm 0.7$ & $18.7 \pm 1.9$ & $180 \pm 20$ & $\mathrm{SD} 2 \mathrm{~h}$ & $9.0 \pm 0.9$ & $19.2 \pm 1.9$ & $110 \pm 10$ & SD3h & $9.5 \pm 0.9$ & $13.7 \pm 1.4$ & $120 \pm 10$ \\
\hline \multirow[t]{3}{*}{ ТP-25 } & $2.0-0.59$ & SE1d & $8.6 \pm 0.9$ & $6.7 \pm 0.7$ & $<100$ & SE2d & $8.3 \pm 0.8$ & $6.6 \pm 0.7$ & $120 \pm 10$ & SE3d & $8.6 \pm 0.9$ & $6.6 \pm 0.7$ & $<100$ \\
\hline & $0.59-0.062$ & SE1g & $6.2 \pm 0.6$ & $3.7 \pm 0.4$ & $<100$ & SE2g & $6.6 \pm 0.7$ & $3.4 \pm 0.3$ & $<100$ & SE3g & $6.5 \pm 0.6$ & $3.7 \pm 0.4$ & $<100$ \\
\hline & $<0.062$ & SE1h & $9.6 \pm 1.0$ & $6.7 \pm 0.7$ & $<100$ & SE2h & $9.8 \pm 1.0$ & $6.6 \pm 0.7$ & $<100$ & SE3h & $10.2 \pm 1.0$ & $6.8 \pm 0.7$ & $<100$ \\
\hline
\end{tabular}




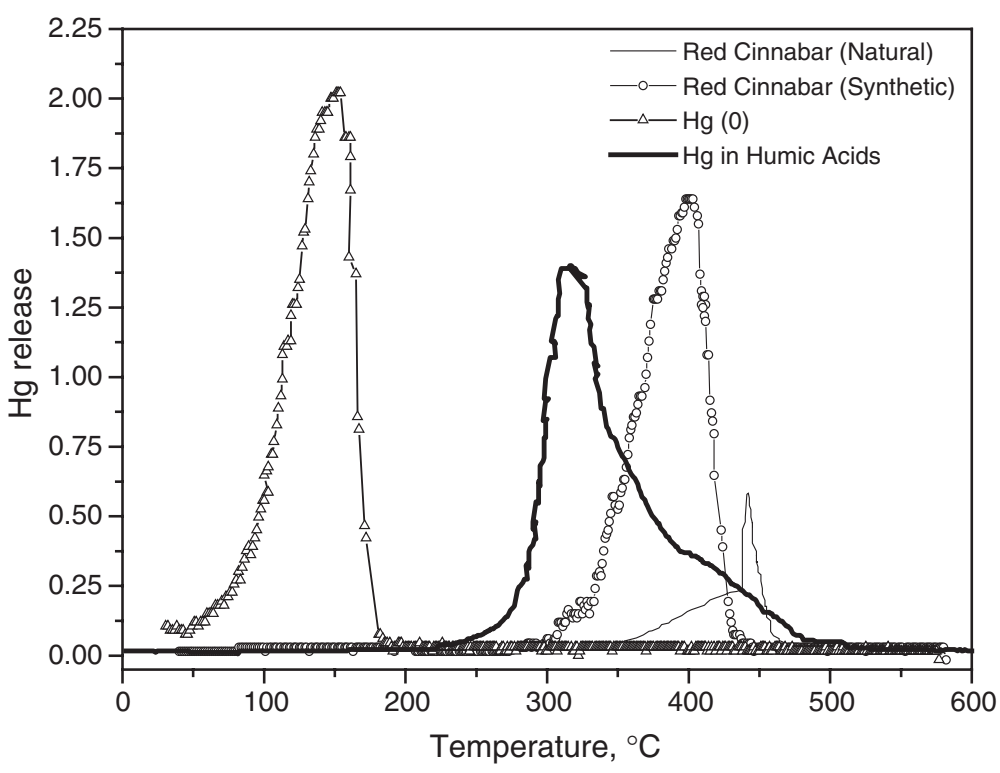

Fig. 3. Comparison of thermal desorption curves of standard mercury compounds.

standard $\mathrm{Hg}$ in humic acid (Fig. 3). Hg release temperatures varied with grain size, indicating a slightly stronger $\mathrm{Hg}$ interaction with the silt and clay fraction (Fig. 4a and c, samples SA2h, SE2h). In some topsoil layer, samples from sites TP-20 and TP-18 and in one sediment sample (SDT) from TP-09, Hg TDCs display a basically bimodal pattern with peaks at about 280 $380{ }^{\circ} \mathrm{C}$ and $400-500{ }^{\circ} \mathrm{C}$ (Fig. 4b). This suggests the presence of mercury bound to organic matter and the existence of red cinnabar as shown in the natural cinnabar curve from the region studied (Fig. 3). According to Biester et al. (2000), the thermal decomposition of red cinnabar shows sharp Hg peaks due to the breakdown of the cinnabar lattice, which causes the sudden release of high amounts of metallic Hg. They also found that the mercury release temperatures of red cinnabar varies slightly with crystallinity and grain size. Synthetic cinnabar (Fig. 3) showed Hg release temperatures lower than those of the fully crystalline cinnabar of the region studied. It is interesting to note that sample SD1h (Fig. 4b) and others that present similar peaks are from the topsoil layer, which indicates a possible detrital origin of cinnabar. According to Alloway (1995), cinnabar is resistant to normal oxidation and weathering processes, and therefore, it enters the geochemical cycle mainly in the form of mechanically degraded particulate material. Metallic mercury is released below $200{ }^{\circ} \mathrm{C}$ (Fig. 3), but it was not detected in the soil samples studied as would be expected in the case of anthropogenic $\mathrm{Hg}$ input due to the gold amalgamation process.
TP-25 samples showed $\mathrm{Hg}$ release temperatures higher than $400{ }^{\circ} \mathrm{C}$ (Fig. 4c), indicating that in these samples, mercury is more strongly bound to the matrix in comparison to the other samples evaluated here. This high release temperature is comparable with that of $\mathrm{Hg}$ bound to ferrihydrite (Valle, 2005). Due to its low crystallinity, this iron oxide presents a large surface area and high reactivity. This hypothesis is quite reasonable, since the soil of TES is rich in iron oxides.

\subsection{Correlation analysis}

With the objective of evaluating correlations between $\mathrm{Hg}$ concentrations and the physico-chemical parameters analyzed at 3 depths and at 5 sites, Pearson linear correlation coefficient test was used. The obtained correlation matrix is presented in Table 3 . TP-25 data were not included in this correlation due to its different behavior, as already demonstrated by $\mathrm{Hg}$ TDCs. The correlations in bold are significant at $p<0.05(N=15)$. As can be seen in Table 3, Hg correlated with organic carbon $(r=0.64)$ and sulfur $(r=0.77)$, and organic carbon strongly correlated with sulfur $(r=0.88)$. Shuster (1991) stated that mercury exhibits a large affinity for organic matter in soils and sediments due to its strong affinity for S-containing functional groups frequently found in organic molecules. Busher (1992) found a significant correlation between $\mathrm{Hg}$ and organic matter content in sediments from Tripuí Stream and observed that sulfur is most likely associated with sulfide minerals, mainly pyrite, 
and possibly with sulfur-bearing organic matter. It was also concluded through thermal desorption technique that $\mathrm{Hg}$ in sediment samples from Carmo River, Minas Gerais, Brazil (FEAM et al., 1999) was mostly associated to humic acids. The results of this study suggest that the $\mathrm{Hg}-\mathrm{S}$-organic matter interaction occurs with a large part of $\mathrm{Hg}$ present in soils. Although the clay and silt $(<0.062 \mathrm{~mm})$ mineralogy of site TP-25 is predom-
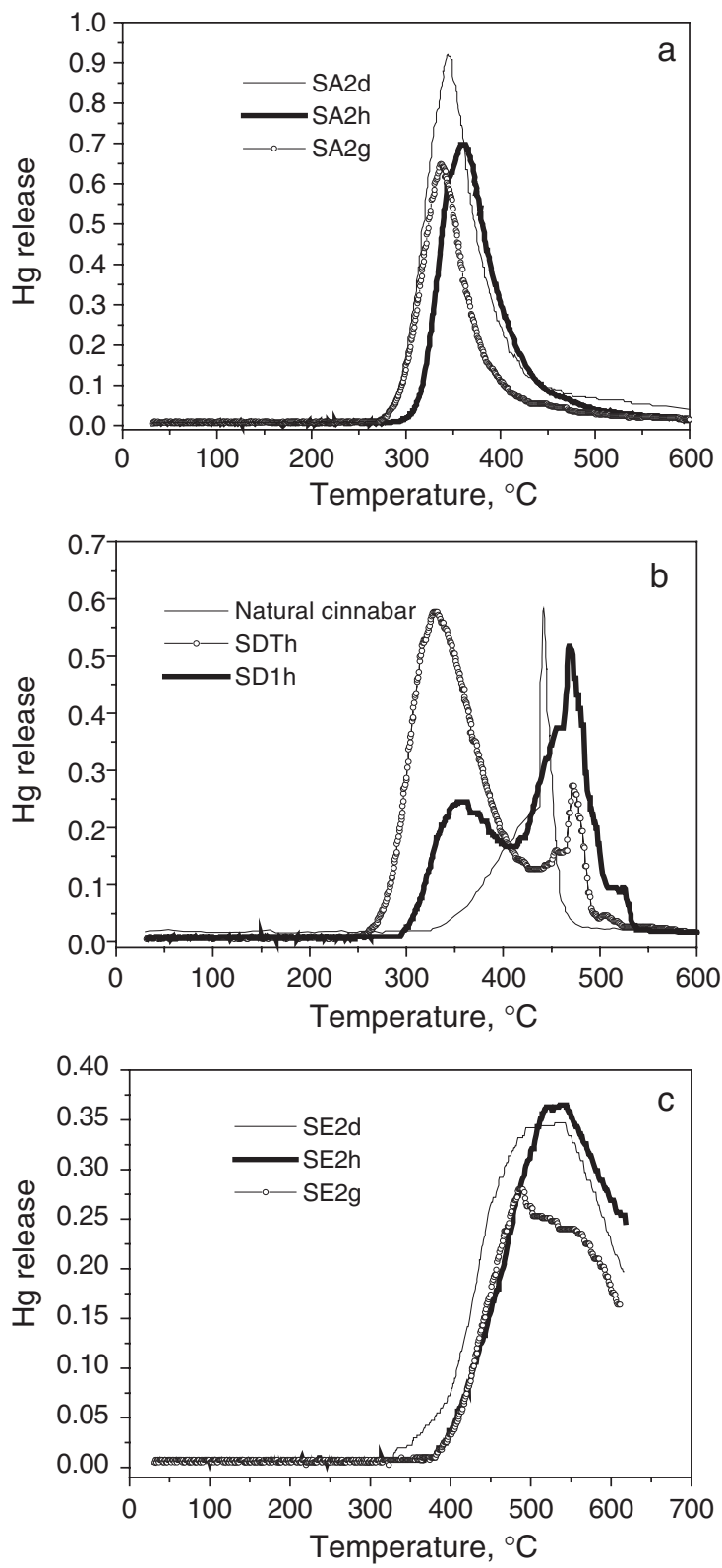

Fig. 4. Hg thermal desorption curves of TES samples: (a) different size fractions of sample SA2; (b) natural red cinnabar; track sediment sample SDTh $(<0.062 \mathrm{~mm})$; soil sample SD1h; (c) different size fractions of sample SE2.
Table 3

Pearson's correlation between selected parameters in soils at three depths $(\mathrm{N}=15, \mathrm{p}<0.05)$

\begin{tabular}{lrrrrrrr}
\hline & Depth & $\mathrm{Hg}$ & $\begin{array}{l}\text { Organic } \\
\text { carbon }\end{array}$ & $\mathrm{pH}$ & $\mathrm{Fl}$ & $\mathrm{S}$ \\
\hline Depth & 1.00 & & & & & & \\
$\mathrm{Hg}$ & -0.14 & 1.00 & & & & & \\
Organic & -0.42 & $\mathbf{0 . 6 4}$ & 1.00 & & & & \\
$\quad$ carbon & & & & & & & \\
pH & 0.28 & 0.28 & 0.22 & 1.00 & & & \\
$\mathrm{Al}$ & 0.13 & -0.16 & 0.11 & -0.03 & 1.00 & & \\
$\mathrm{Fe}$ & -0.05 & 0.01 & -0.39 & -0.06 & $-\mathbf{0 . 7 4}$ & 1.00 & \\
$\mathrm{~S}$ & -0.27 & $\mathbf{0 . 7 7}$ & $\mathbf{0 . 8 8}$ & 0.45 & -0.12 & -0.10 & 1.00 \\
\hline
\end{tabular}

inantly of minerals quartz, kaolinite and muscovite and lesser amounts of hematite, goethite and gibbsite, thermal desorption results suggest that $\mathrm{Hg}$ is strongly bound as in Hg-ferrihydrite (Valle, 2005).

\subsection{Mercury distribution in soil profiles}

Mercury concentration profiles (30,60 and $90 \mathrm{~cm})$ at six TES sites are shown in Fig. 5. The mercury concentration at each depth was calculated by the weighted mean of the $\mathrm{Hg}$ concentration in the three different grain sizes studied. In most sites, $\mathrm{Hg}$ was homogeneously distributed throughout the depths. At TP-09, the concentration of $\mathrm{Hg}$ decreased with the depth, whereas at TP-25, the opposite was observed. The retention of $\mathrm{Hg}$ at TP-09 is probably related with the organic carbon content (Anderson, 1979), which is the highest in the topsoil layer. The low organic carbon content, acid $\mathrm{pH}$ and the oxidizing conditions (Fergusson, 1990) may explain the presence of $\mathrm{Hg}$ in the deepest layer at TP-25. Within the soil profiles, organic matter content was the highest in the surface horizon, and the concentrations of $\mathrm{Fe}, \mathrm{Al}$ and $\mathrm{S}$ were almost always homogeneously distributed throughout the depths. According to Fergusson (1990), variations in the concentrations of heavy elements in soil profile are not consistent and are as readily interpreted as in water and sediment profile. Several factors can influence the level of an element in a soil profile: the nature of the parent material, pedogenic process, organic and clay content, proportion of iron-containing minerals, $\mathrm{pH}$, soil topography, rainfall, microbial activity and the level of pollution. The relevance of the factors will vary from site to site.

\section{Conclusions}

The distribution of mercury in TES soils presented $\mathrm{Hg}$ concentrations ranging from 0.09 to 


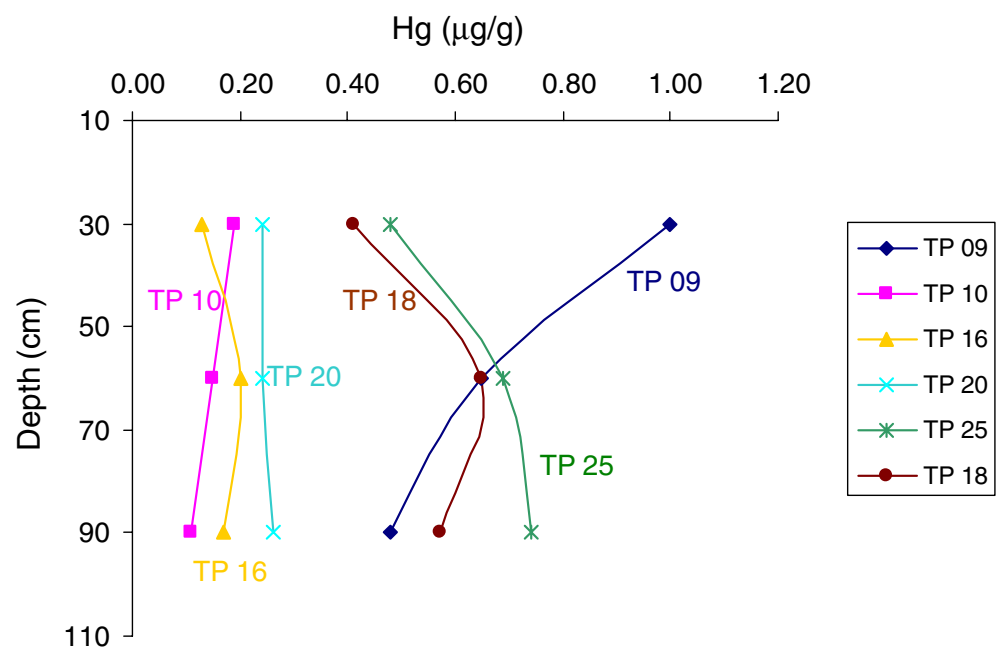

Fig. 5. Mercury profiles at six sites in Tripuí Ecological Station.

$1.23 \mu \mathrm{g} / \mathrm{g}$. The highest contents were found at the site nearest to an abandoned cinnabar mine, TP-09, and at the sites that receive direct influence from this mine through Botafogo Stream (TP-18 and TP20). Although Fortes pond (TP 25) was not affected by the cinnabar mine, it showed a high $\mathrm{Hg}$ content. As $\mathrm{Hg}^{0}$ was not detected in soil samples, it can be concluded that if there were metallic $\mathrm{Hg}$ input through gold amalgamation process in past times, it was oxidized to $\mathrm{Hg}^{2+}$ and sorbed onto soil components.

The results showed that $\mathrm{Hg}$ concentration depends on the distribution of different soil grain size fractions. $\mathrm{Hg}$ concentration was similar in the sand size fraction $(2-0.59 \mathrm{~mm})$ and in the silt and clay size fraction $(<0.062 \mathrm{~mm})$ of all soil layers studied. The same was observed for $\mathrm{Fe}, \mathrm{Al}$ and organic matter, with the exception of site TP-25.

TDCs revealed the presence of mercury in the form of $\mathrm{Hg}^{2+}$ bound to organic components in most of the samples as well as the presence of red cinnabar in some. Data correlation analysis confirmed that mercury is associated with organic matter and sulfur and possibly with sulfur-bearing organic matter in soils.

The results suggest that mercury has been introduced into the soils along the years mainly via erosion process in the abandoned cinnabar mine rather than by anthropogenic origin.

\section{Acknowledgements}

We acknowledge the cooperation of the State Forest Institution (I E F) of Minas Gerais for allowing the collection of samples at the Tripuí Ecological Station.

\section{References}

Alloway BJ. Heavy metals in soils. London: Blackie Academic \& Professional; 1995. 368 pp.

Anderson A . Mercury in soils. In: Nriagu JO. The Biogeochemistry of Mercury in the Environment. Elsevier, North-Holland: Biomedical Press, 1979, pp. 79-112.

Azzaria LM, Webber GR. Mercury analysis in geochemical exploration. Can Min Metall (CIM) Bull 1969;521-30 [May].

Biester H, Gosar M, Covelli S. Mercury speciation in sediments affected by dumped mining residues in the drainage area of the Idrija mercury mine, Slovenia. Environ Sci Technol 2000;34: $3330-56$.

Busher, DP, (1992). Mercury in river sediments from Garimpeiro activities in the vicinity of Ouro Preto, Minas Gerais, Brazil. M.Sc. Thesis, Faculty and Board of Trustees of the Colorado School of Mines, Golden, Colorado, 140 pp.

Cruz, LV, (2002). Avaliação Geoquímica Ambiental da Estação Ecológica do Tripuí e Adjacências, Sudeste do Quadrilátero Ferrífero, MG. M.Sc. Thesis, Federal University of Ouro Preto, Minas Gerais, Brasil, 147 pp.

EMBRAPA/Empresa Brasileira de Pesquisa Agropecuária S. Manual de métodos de análise do solo. 2 ed. Rio de Janeiro: Centro Nacional de Pesquisa de Solos; 1997. 212 pp.

Eschewge WL, 1979. Pluto Brasiliensis Col Reconquista do Brasil Itatiaia, Belo Horizonte. São Paulo: USP; 1979. p. 165-6.

FEAM, SES, FUNED, CDTN. 1999. Pesquisa da Contaminação por Mercúrio em Garimpo do Estado de Minas Gerais, seu Impacto na Saúde e no meio Ambiente: relatório técnico final. Belo Horizonte, Minas Gerais, Brasil, v. 1, 182 pp.

Fergusson JE. The heavy elements. Chemistry, environment impact and health effects. Oxford: Pergamon Press; 1990. 614 pp.

Guimarães Neto, AS. Estação Ecológica do Tripuí, Ouro Preto, MG. 1999, http://www.em.ufop.br/op/tripui.htm. Date of access: Oct 2003.

Higueras P, Oyarzun R, Biester H, Lillo J, Lorenzo S. A first insight into mercury distribution and speciation in soils from 
the Almadén mining district, Spain. J Geochem Explor 2003; 80:95-104.

Leoni L, Sartori F. Heavy metals and arsenic distributions in sediments of the Elba-Argentino basin, southern Tuscany, Italy. Environ Geol 1997;32:83-92.

Mierle G, Ingram R. The role of humic substances in the mobilization of mercury from watersheds. Water Air Soil Pollut 1991;56: $349-57$.

Moore JW, Ramamoorthy S. Heavy metals in natural waters. New York: Springer-Verlag; 1984.

Palmieri HEL, Leonel LV, Nalini HA, Cruz LV. Mercury assessment in plants from Trupuí Ecological Station, Minas Gerais, Brazil. In: Neves M.V, Neves ACV, editors. Int Symp Environment 2010: Situations and Perspectives for European Union, 6-10 May 2003, Porto, Portugal, paper B 13.

Raposo C, Windmöller CC, Durão Jr WA. Mercury speciation in fluorescent lamps by thermal release analysis. Waste Manag 2003;23:879-86.

Salomons W, Förstner U, Mader P. Heavy metals, problems and solutions. . Berlin: Springer-Verlag; 1995. 412 pp.

Shuster E. The behavior of mercury in the soil with special emphasis on complexation and adsorption process - a review of the literature. Water Air Soil Pollut 1991;56:667-80.
Steinnes E. Mercury. In: Alloway BJ, editor. Heavy metals in soils London: Blackie Academic \& Professional; 1995. p. 245-59.

Tessier A, Campbell PGC, Bisson M. Particulate trace metal speciation in stream sediments and relationship with grain size: implication for geochemical exploration. J Geochem Explor 1982;6: $77-104$

Valle, CM, (2005). Especiação, Quantificação, Distribuição e Comportamento Redox do Mercúrio em alguns Solos de Manaus, Amazonas, Brasil. Ph.D. Thesis, Chemistry Department, Federal University of Minas Gerais, Belo Horizonte, Minas Gerais, $105 \mathrm{pp}$.

Windmöller CC, Wilken RD, Jardim WF. Mercury speciation in contaminated soils by thermal release analysis. Water Air Soil Pollut 1996;89:399-416.

Xia K, Skyllberg UL, Bleam WF, Bloom PR, Nater EA, Helmke PA. $\mathrm{X}$-ray absorption spectroscopic evidence for the complexation of $\mathrm{Hg}(\mathrm{II})$ by reduced sulfur in soil humic substances. Environ Sci Technol 1999;33:257-61. 